\title{
Paleocene Seismic Facies in the Continental Margin of Uruguay (South AMERICA)
}

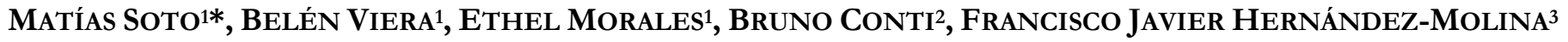

1 Instituto de Ciencias Geológicas, Facultad de Ciencias, Iguá 4225, 11400 Montevideo, Uruguay

2 Exploración y Producción, Administración Nacional de Combustibles, Alcohol y Portland, Libertador s/n y Paysandú, 1100 Montevideo, Uruguay

3 Department of Earth Sciences, Royal Holloway University of London, TW20 OEX Egham, England

*CORRESPONDING AUTHOR, msoto@ffien.edu.uy

\author{
Received on 1 September 2018 \\ Received in revised form on 23 July 2019 \\ Accepted on 24 July 2019
}

\section{Editor: Leticia Burone, Universidad de la República, Uruguai}

\section{Abstract}

In this contribution seismic facies of the Paleocene sequence are characterized in offshore basins of Uruguay through the study of a $2 \mathrm{D}$ seismic database. Seven seismic horizons were identified, limiting six sedimentary intervals with different characteristics. Hence, the complexity of the Paleocene sequence is greater than suggested by other studies. Seismic facies located in the basis of the sequence can be interpreted as sandy deposits related to the action of both turbidity and

\section{Introduction}

During the Late Cretaceous, more than 200 meters of Cretaceous fluvial conglomerates and sandstones were deposited in the Northern Basin (also Littoral Basin; Goso and Perea, 2004). However, during the Paleocene and Eocene the onshore territory of Uruguay did not function as an area of accumulation of sediments, i.e. no depositional events were recorded until the Oligocene (Martínez and Veroslavsky, 2004). However, different epigenetic processes (the exact age of which is still under debated, but probably are comprised between the latest Cretaceous and the Paleogene) did occur. Ferricretes, calcretes and silcretes were generated, affecting mainly the Late Cretaceous deposits (Mercedes and Asencio formations) widely exposed at that epoch, but also basement rocks, Early Devonian deposits and Early Cretaceous basalts of the Arapey Formation (Goso and Perea, 2004; Martínez and Veroslavsky, 2004). As a result of this phenomena even pure limestones were formed (Queguay Formation), currently in exploitation for the cement industry, as well as curious columnar ferruginous structures, such as those observed in the so-called Grutas del Palacio (flagship of the UNESCO geopark of the same name) and other localities.
Citation:

Soto, M., Viera, B., Morales, E., Conti, B., Hernández-Molina, J.H., 2019. Paleocene seismic facies in the continental margin of Uruguay (South America). Journal of Sedimentary Environments, 4 (3): 263-275.

bottom currents. The identification of these deposits agrees with the expected Cretaceous source rocks, in addition to the importance of the overlying Paleocene shales as a regional seal. The results of this work open interesting exploratory perspectives in the continental margin of Uruguay.

Keywords: Paleocene. Seismic Facies. Uruguayan Continental Margin.

In clear contrast, in the offshore basins of Uruguay (Punta del Este and Pelotas basins), the Paleocene-Eocene was a period of important sediment deposition. This is especially true for the distal sectors of the continental margin.

The objective of this work is to characterize and describe the different seismic facies which can be identified in the Paleocene sequence. The Eocene sequence was recently addressed by Viera et al. (2018). In the Lobo and Gaviotín Wells, drilled in the Punta del Este Basin by Chevron in 1976 (Fig. 1), the Paleocene sequence is composed mainly of shales and siltstones (Fig. 2), and secondarily by fine grained sandstones. This sequence, with a lithostratigraphic framework corresponding to the base of the Gaviotín Formation (Ucha et al., 2004), reaches in the homonymous well about $160 \mathrm{~m}$ (Daners and Guerstein, 2004), much less than in distal sectors of the continental margin. It is noteworthy that only the Danian stage is represented in the well area. The base of the Paleocene sequence in the Uruguayan continental margin corresponds to an important unconformity, in fact one of the most conspicuous unconformities of the margin. This surface was covered by a transgression of regional extent. For the first time in the 
history of the margin, this allowed that sedimentation surpassed the internal basement highs, namely the Polonio High (which separates the Punta del Este and Pelotas basins) and the Plata High (which separates the Punta del Este and Salado basins). Although transgressive events were recorded since the Aptian stage in distal sectors of this margin, and it was only in the Late Maastrichtian-Paleocene that marine sedimentation reached the area of the Lobo and Gaviotín wells. According to Daners and Guerstein (2004), the top of the sequence is, in the well area, the Danian-Lutetian unconformity (i.e. Upper Paleocene and Lower Eocene was eroded).

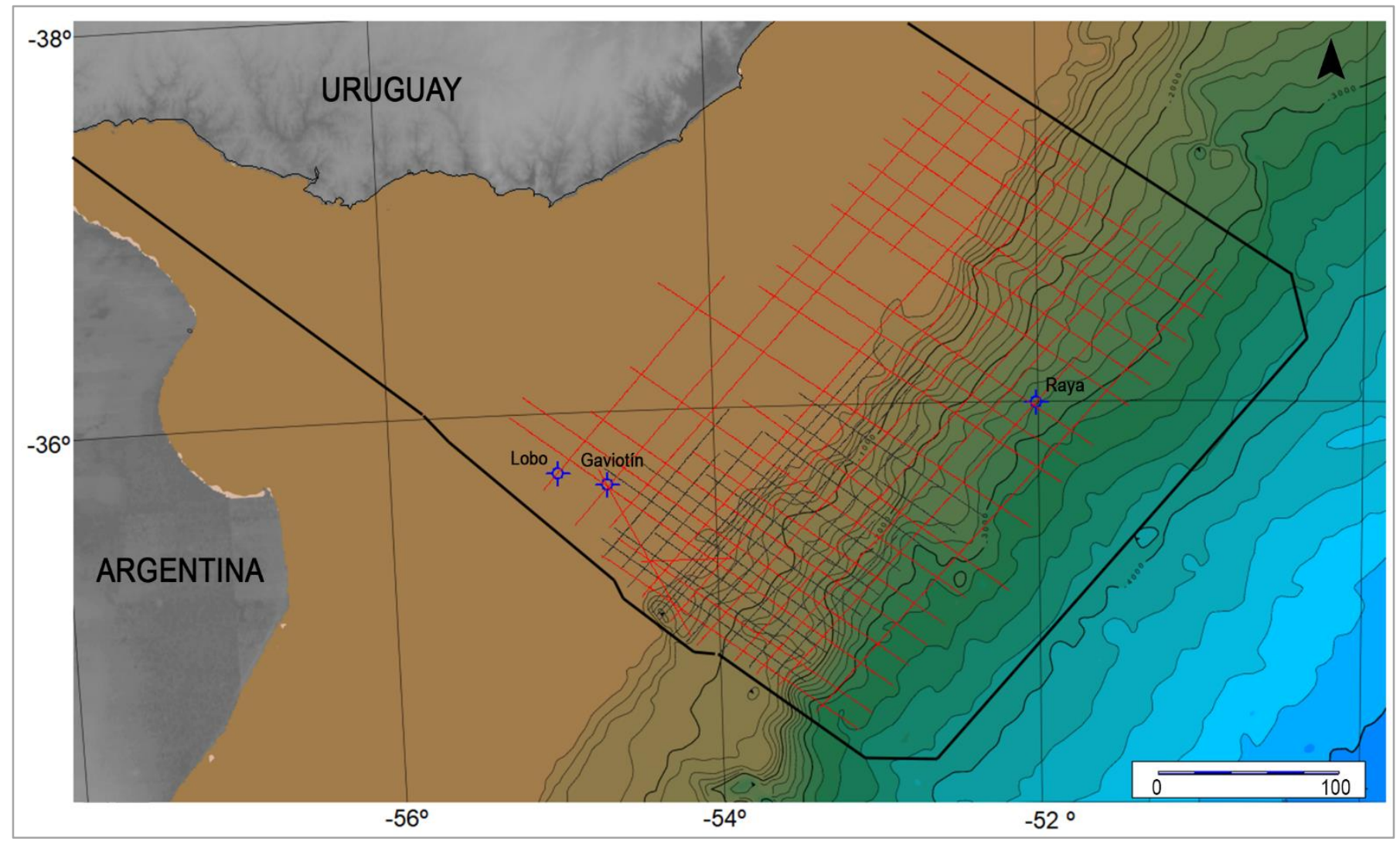

Fig. 1. 2D seismic grid database used in this work. Location of the three wells drilled in the Uruguayan continental margin is also provided. Scale in kilometers.

\section{Materials and Methods}

In this work 55 multichannel reflection seismic profiles were analyzed, totaling $10,000 \mathrm{~km}$. They were acquired in 2007 and 2008 and are currently property of ANCAP, the national oil company of Uruguay. Seismic sections were interpreted employing the software The Kingdom Suite 2016.1 (IHS).

The methodology employed herein was Sequence Stratigraphy (Catuneanu, 2006; Catuneanu et al., 2009). Stratal terminations, stacking patterns and internal configurations were characterized, which allowed to identify several seismic facies. Given the quality of the seismic sections and considering that the sequence locally is eroded, in this study neither depositional sequences nor system tracts were defined.
The horizons which bound the base and top of the Paleocene sequence are those named $\mathrm{H} .8$ and H.9 by Morales et al. (2017a). According to Conti et al. (2017) and Creaser et al. (2017), the ages of these horizons are top Cretaceous and top Paleocene, respectively (Fig. 3A), although other authors have different interpretations (Raggio et al., 2011; Hernández-Molina et al., 2017).

\section{Results}

The Paleocene sequence (Fig. 3) is developed along all the Uruguayan continental slope, as well as in shelf areas in the western portion (Punta del Este Basin). The sequence shows its greatest development in the southeast sector of the continental margin of Uruguay. In the central sector of the margin, the sequence experienced a huge erosion. 


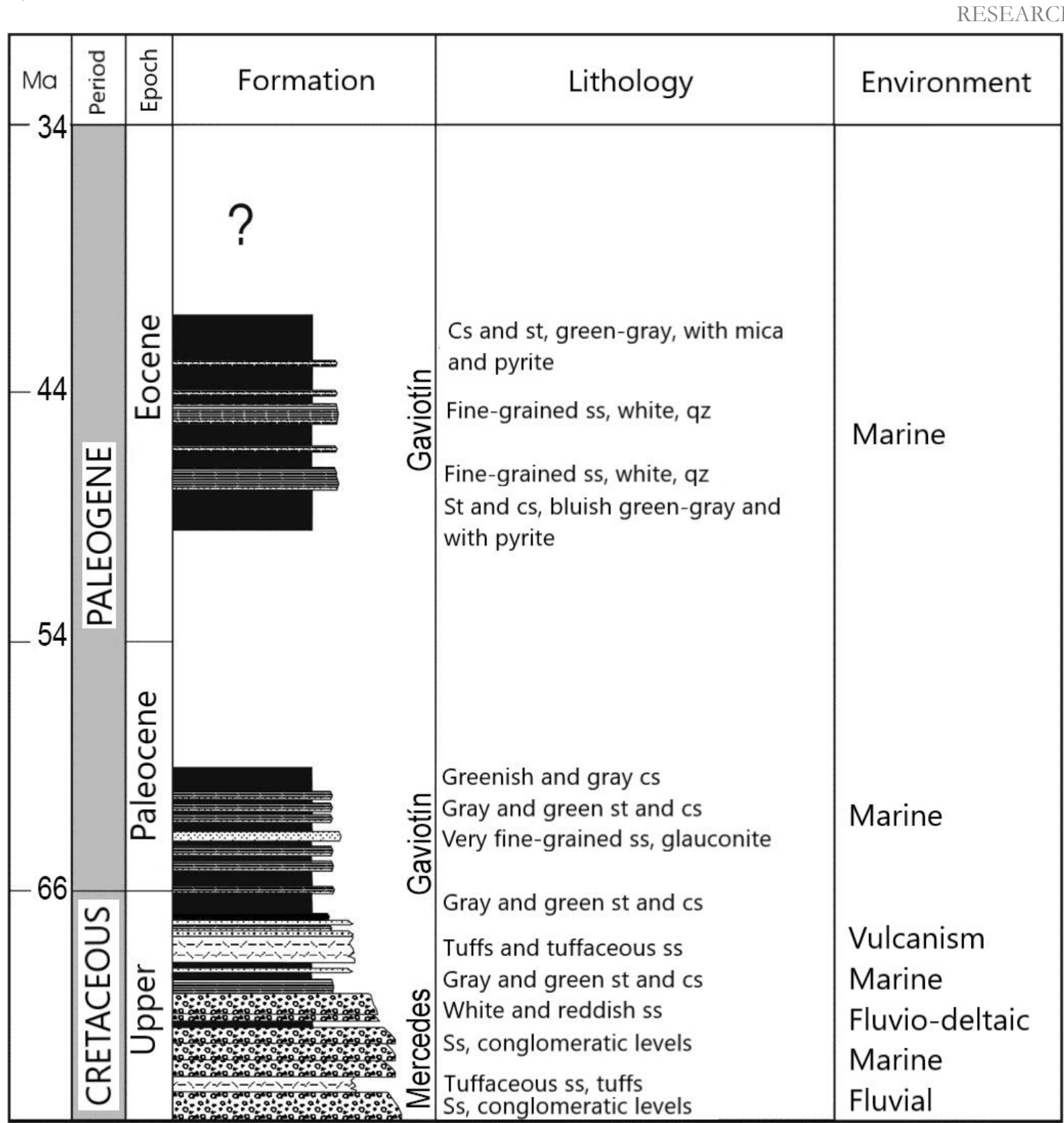

Fig. 2. Lithological column from the latest Cretaceous-Eocene in the Gaviotín well. Modified from Daners and Guerstein (2004). Abbreviations: cs - claystone; qz - quartz; ss - sandstone; st - siltstone.

Within this sequence seven seismic horizons were identified (S1 to S7), which bound packages with different seismic attributes, indicating changes in depositional settings. Hence, the Paleocene sequence is more complex than originally envisaged by Conti et al. (2017) and Morales et al. (2017a). Horizons S1 to S7 limit six sedimentary intervals (Fig. 3), each of these with characteristic seismic facies, reflection terminations and stacking pattern (Table 1).

Interval 1 is bounded by horizons S1 (below) and S2 (above) (Fig. 4A). The basal surface (S1) is defined as an unconformity due to the presence of clear truncations immediately below it. Above horizon S1, downlaps were identified and, more distally, double downlaps. Above horizon S2, in turn, downlaps and channel fill onlaps are present. Interval 1 is restricted to the SW sector of the Uruguayan continental margin, in distal areas (Fig. 5). Maximum thickness is $0.38 \mathrm{~s}$ (TWT). This interval is characterized by conspicuous mounded external configurations. Reflections are relatively discontinuous, chaotic to slightly mounded, and become subparallel towards the top of the sequence, with medium to low amplitudes (Fig. 5). Laterally, these facies disappear towards the Pelotas Basin.

Interval 2 is bounded by horizons S2 (below) and S3 (above). Downlaps are identified above horizon S3. Interval 2 develops in the continental slope region along all the margin, but it is more developed in the Pelotas Basin (Fig. 4B), where it reaches a maximum thickness of $0.36 \mathrm{~s}$ (TW'T). 
Representative seismic facies include parallel to subparallel sector; Fig. 6), as well as slightly mounded reflections, with reflections, with high amplitude and good continuity (central low amplitude and poor continuity.
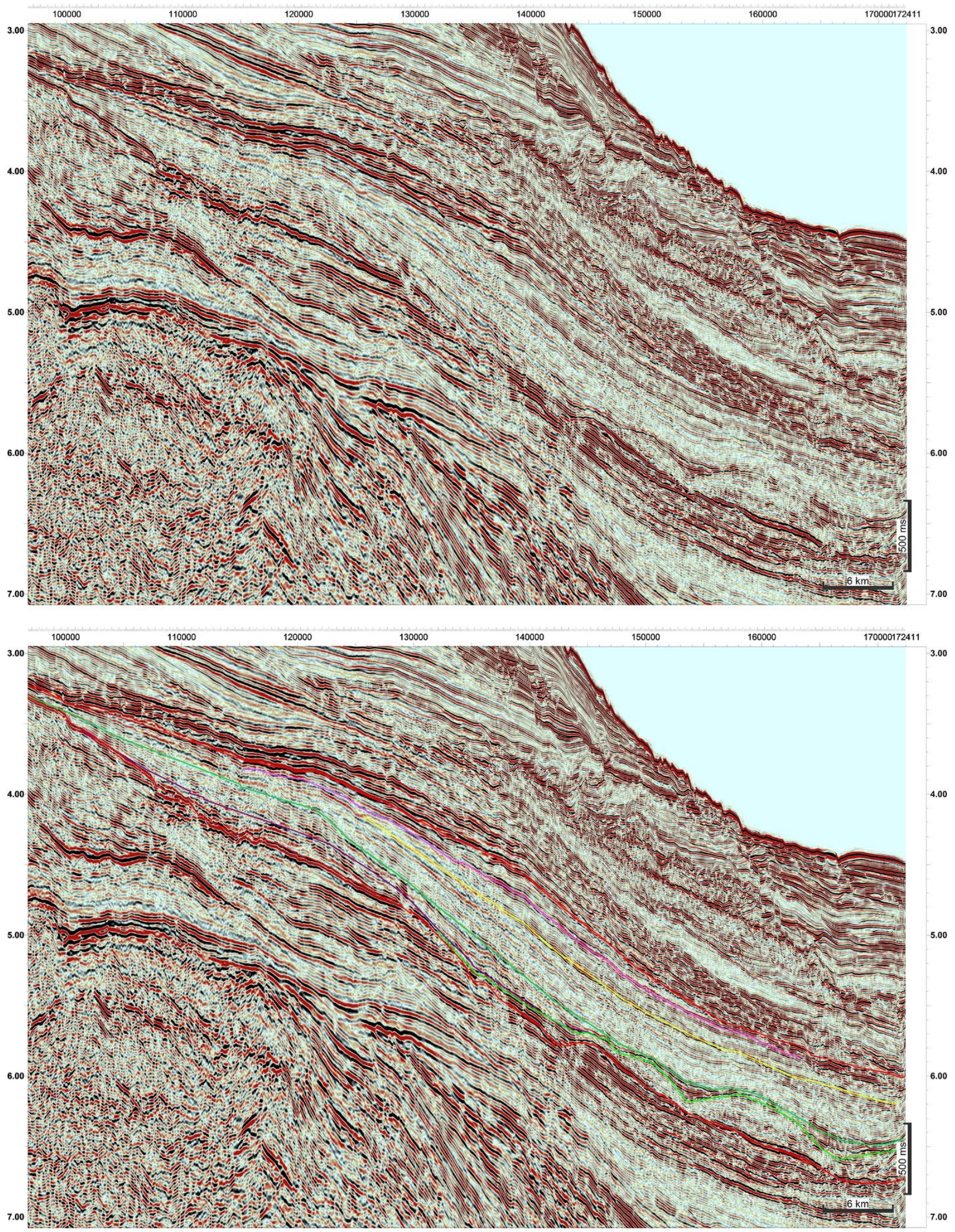

Fig. 3. Representative dip seismic line (both uninterpreted and interpreted) highlighting the Paleocene sequence and the seven identified horizons. Reflection termination not shown for clarity. 


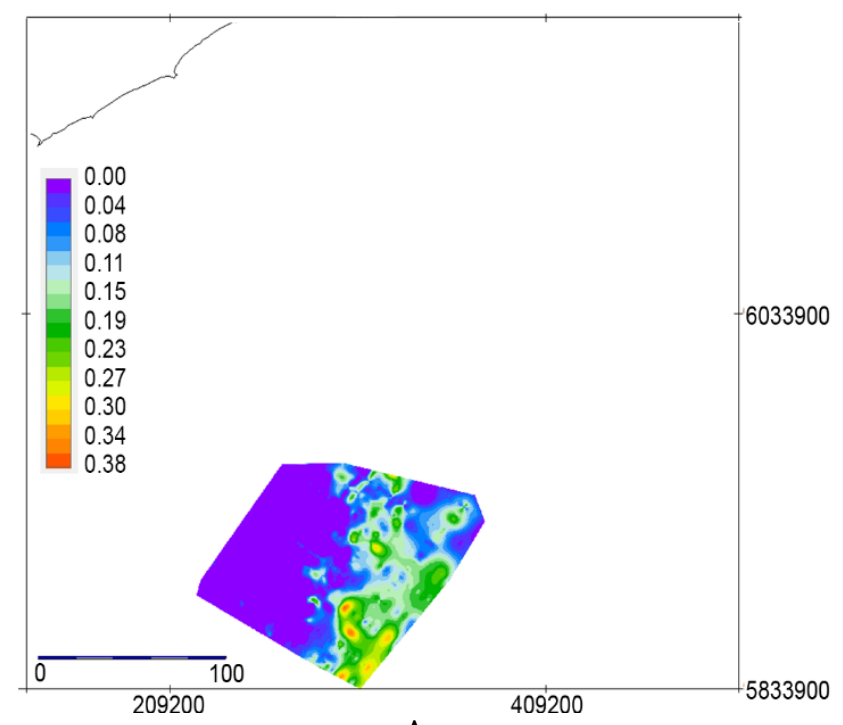

A.

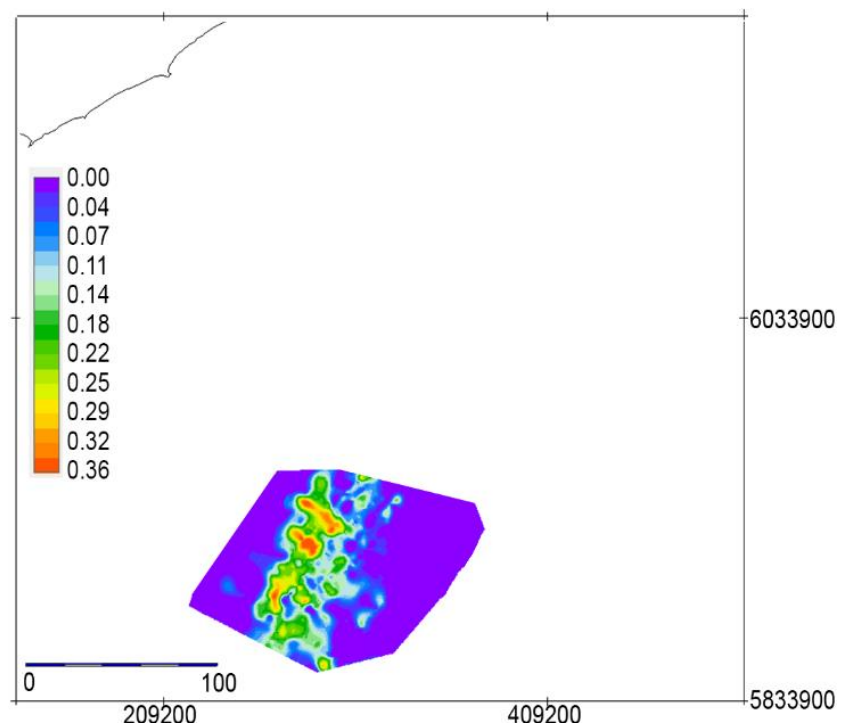

B.

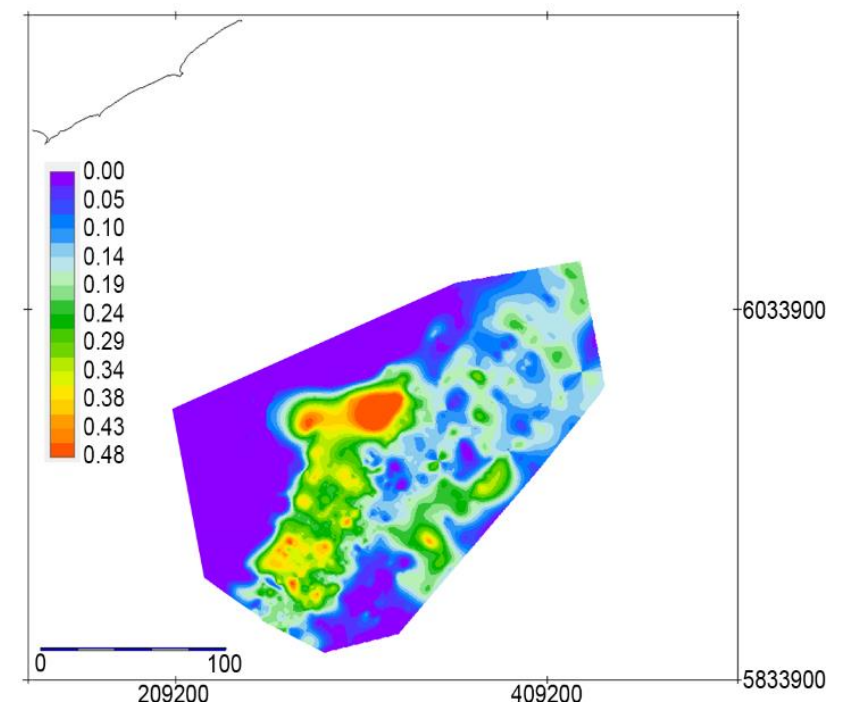

C.
RESEARCH PAPER

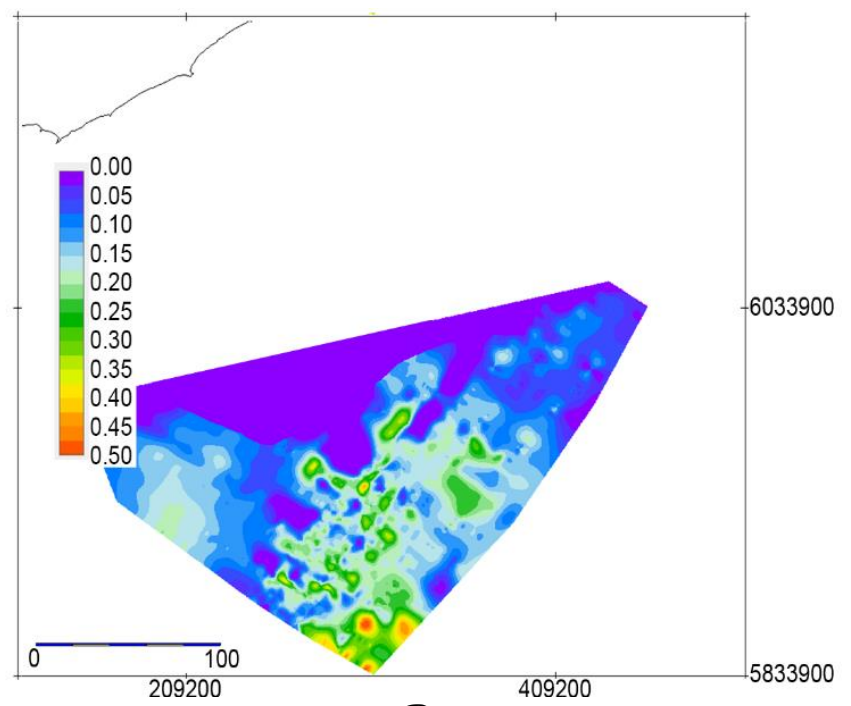

D.

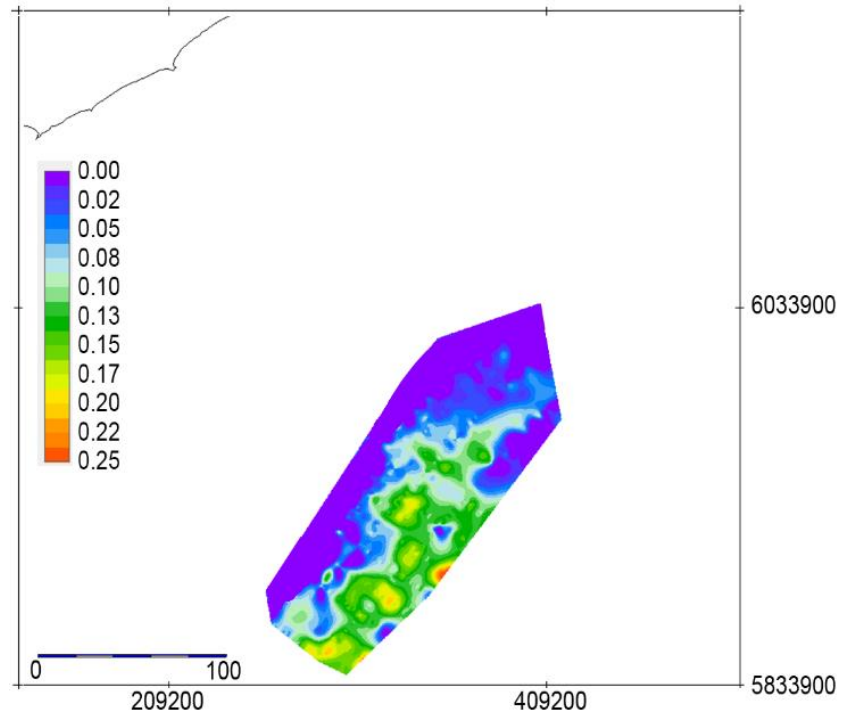

E.

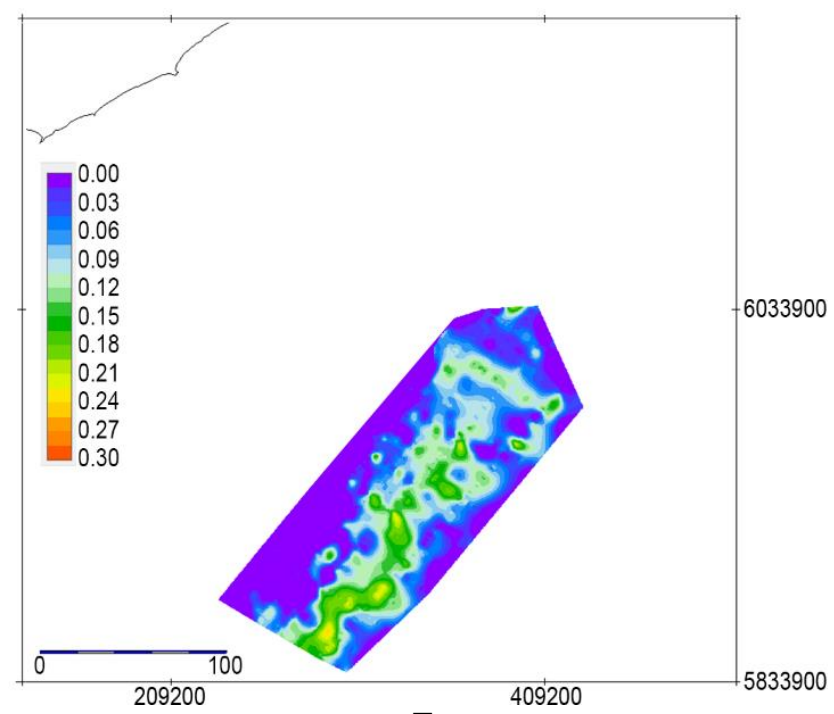

F.

Fig. 4. Isopach map (TWT in s) of: A. Interval 1. B. Interval 2. C. Interval 3. D. Interval 4. E. Interval 5. F. Interval 6. Scale in kilometers. 

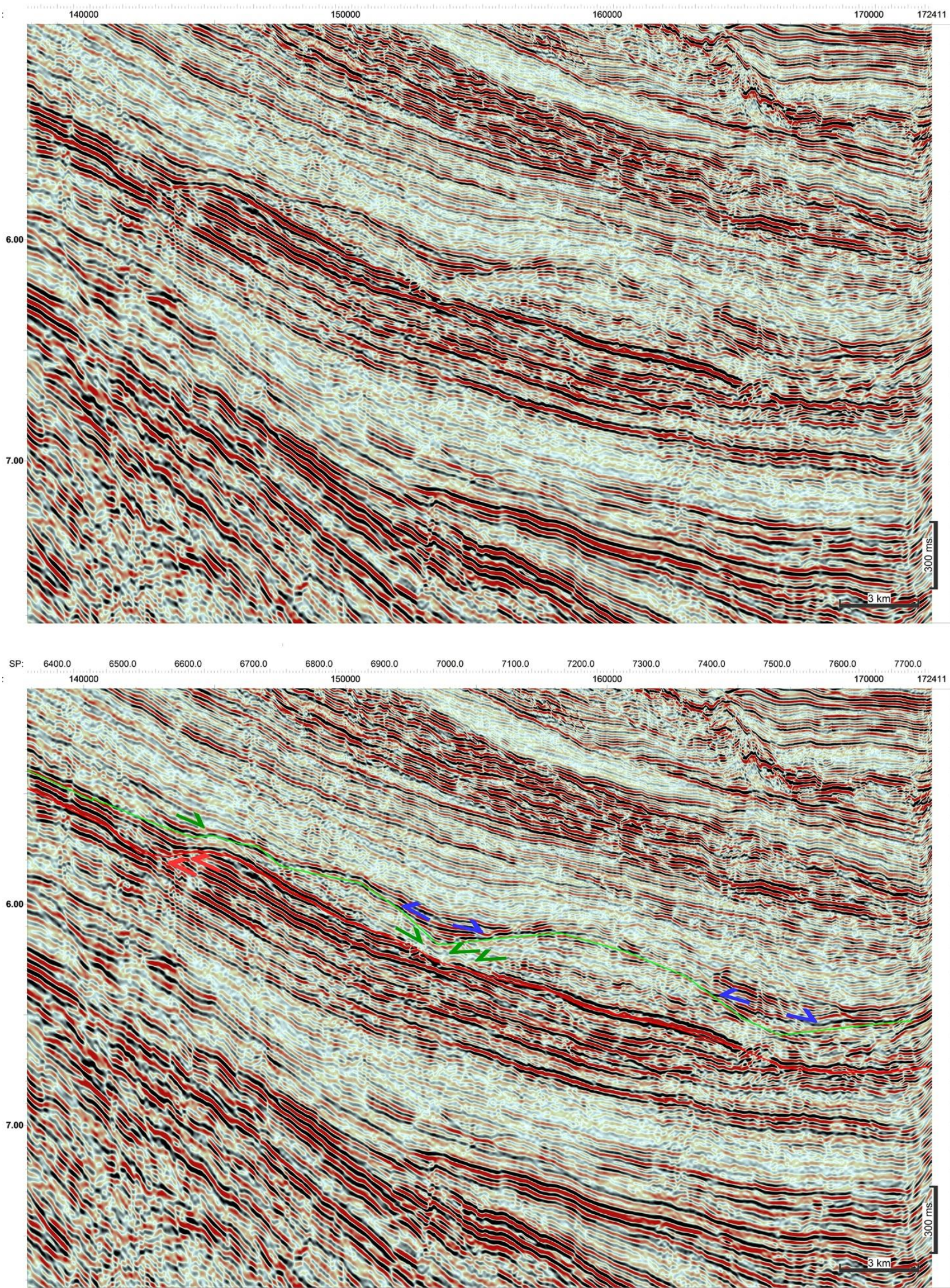

Fig. 5. Uninterpreted and interpreted 2D dip seismic line showing representative seismic facies of Interval 1. Reflection terminations are shown. Vertical scale in TWT (s). 

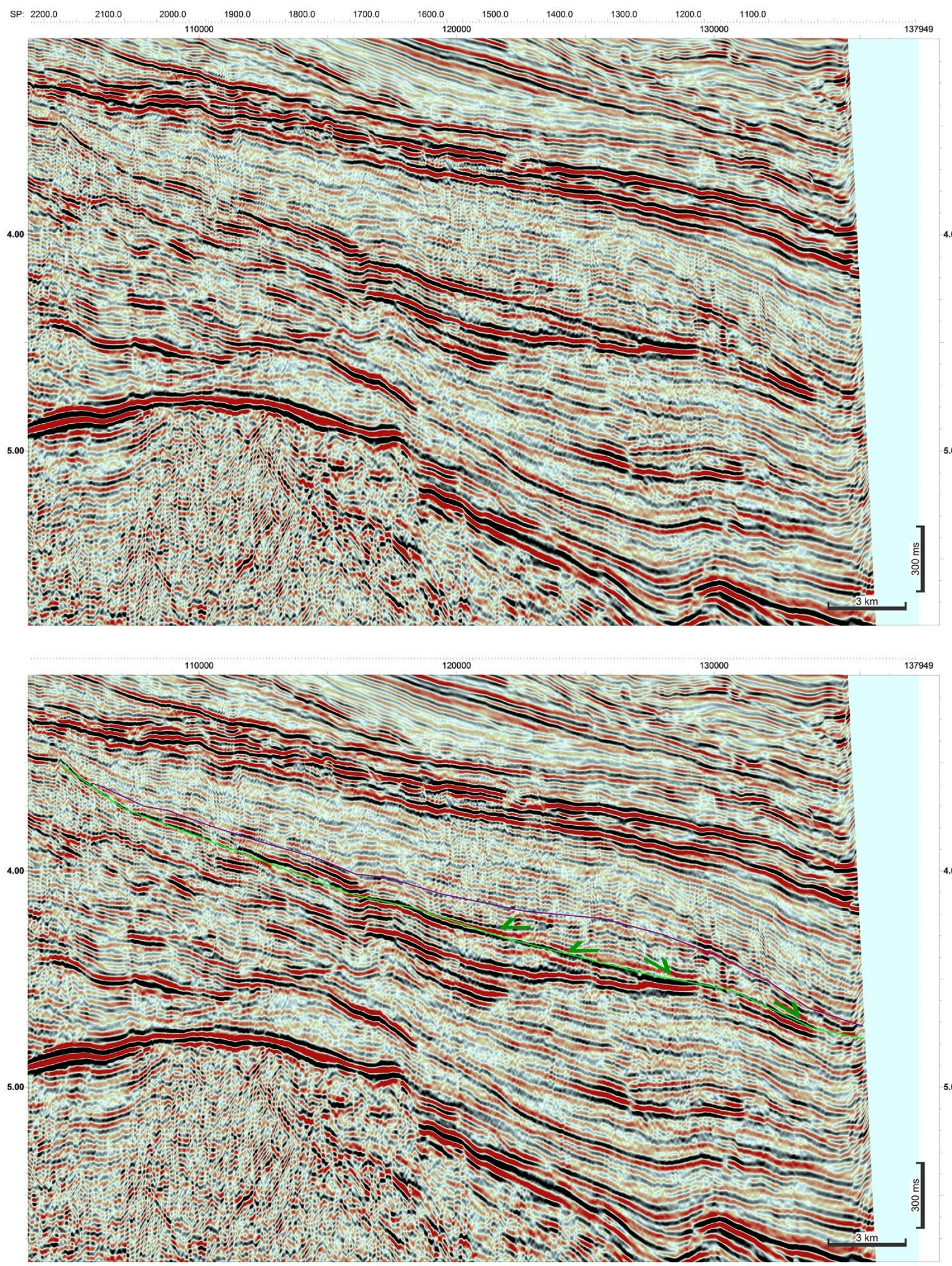

Fig. 6. Uninterpreted and interpreted 2D dip seismic line showing representative seismic facies of Interval 2. Reflection terminations are shown. Vertical scale in TWT (s) 
Interval 3 is bounded by horizons S3 (below) and S4 (above). Horizon S4 shows truncations below and onlaps above it, which is typical of a base level rise. Development of interval 3 is similar to that of Interval 4, although the former reaches slightly distal positions (Fig. 4C). Maximum thickness reaches $0.48 \mathrm{~s}$ (TW'T). Seismic facies include subparallel reflections, of medium to low amplitude and poor continuity (Fig. 7).
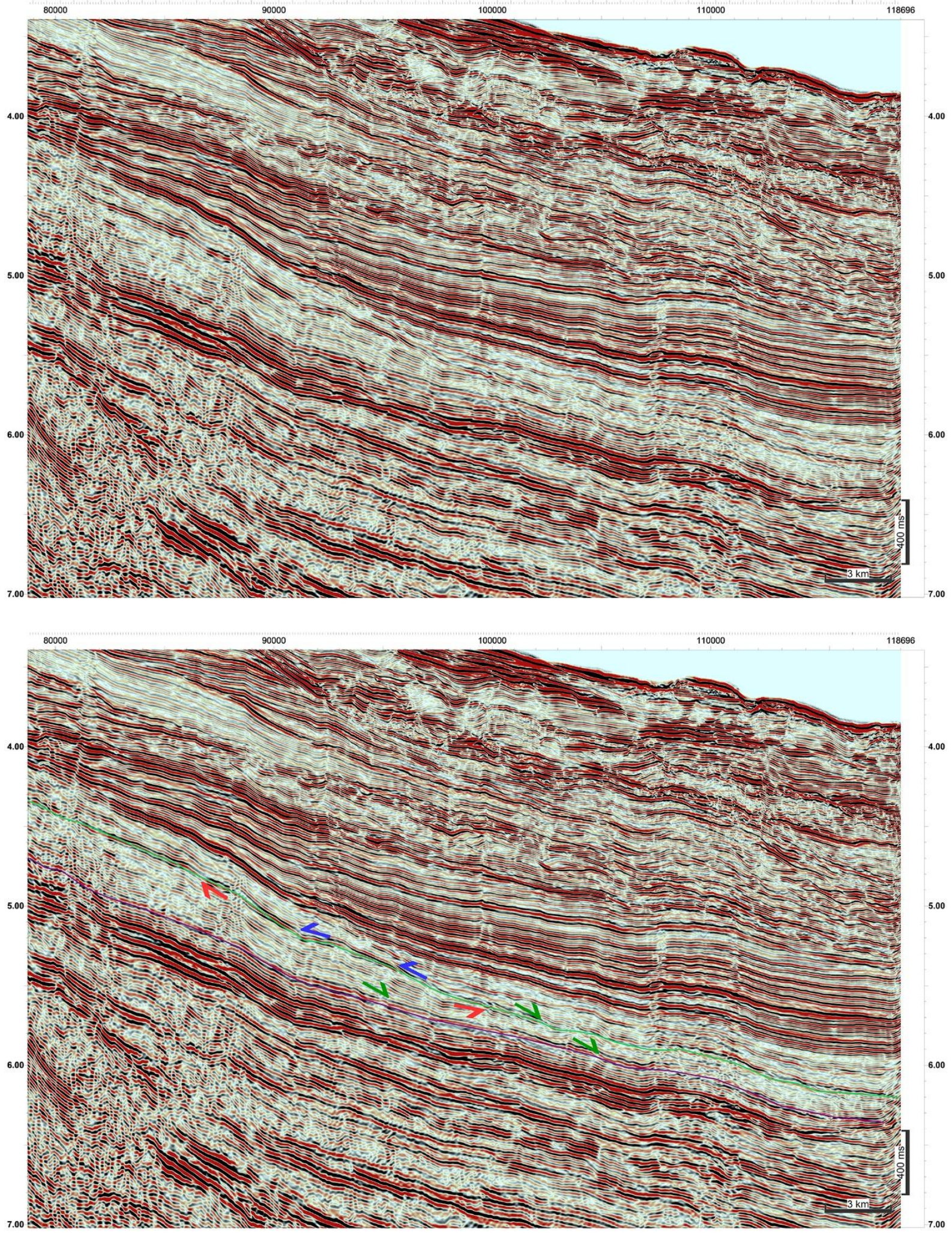

Fig. 7. Uninterpreted and interpreted 2D dip seismic line showing representative seismic facies of Interval 3. Reflection terminations are shown. Scale in kilometers. 
Interval 4 is bounded by horizons S4 (below) and S5 (above). Above horizon S5 both onlaps and downlaps are observed (central and distal sectors, respectively).

Interval 4 is the more widespread of all sedimentary intervals recognized in the Paleocene sequence (Fig. 4D). It reaches $0.50 \mathrm{~s}$ in thickness (TWT). Interval 4 show
RESEARCH PAPER

subparallel reflections, with low amplitude and continuity in proximal sectors, becoming rather parallel, with medium (locally high) amplitude and greater continuity in distal positions.

There the reflections cover the mounded paleotopography of Interval 1 (Fig. 8).
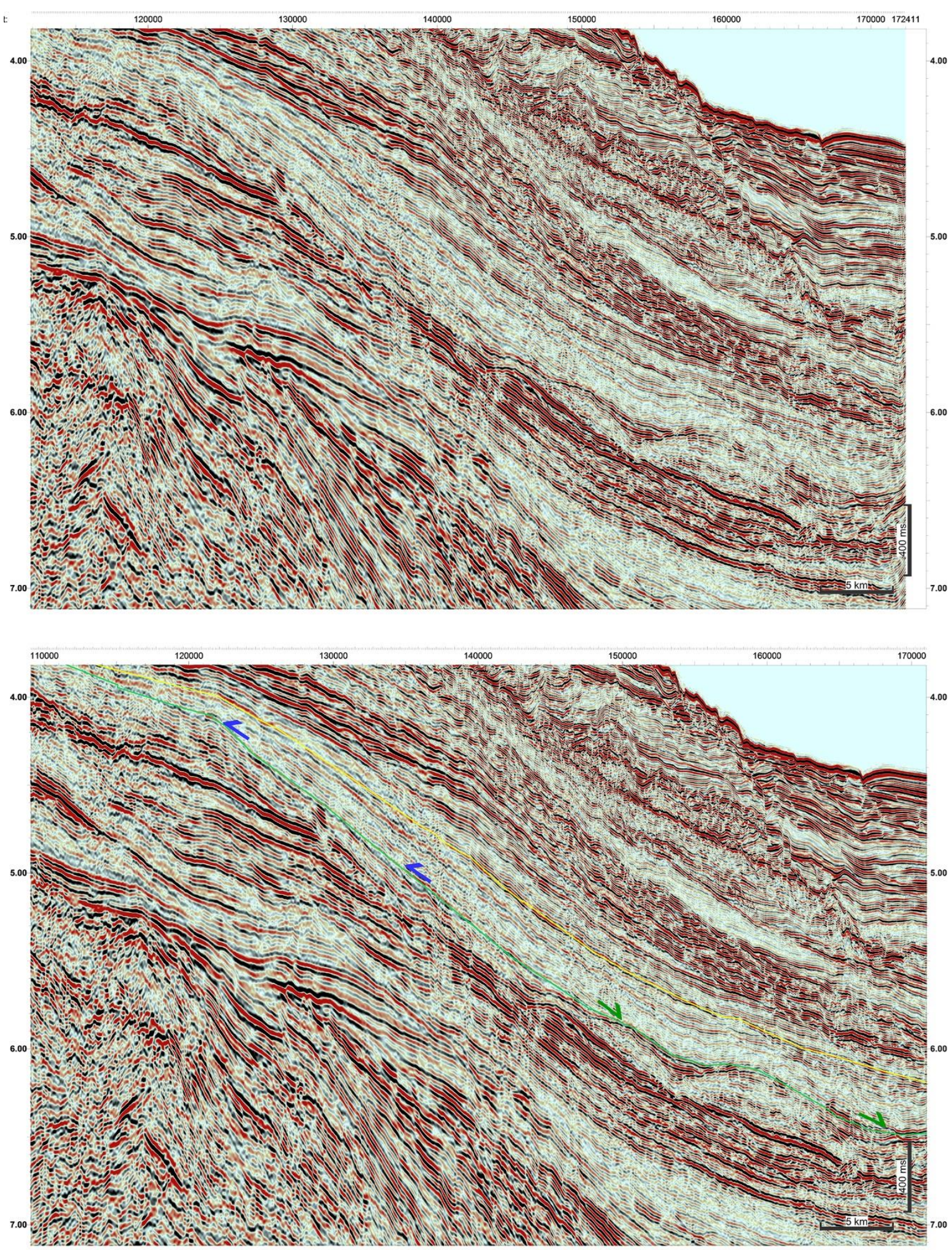

Fig. 8. Uninterpreted and interpreted 2D dip seismic line showing representative seismic facies of Interval 4. Reflection terminations are shown. Vertical scale in TW'T (s). 
Interval 5 is bounded by horizons S5 (below) and S6 (above). As in horizon S5, both onlaps and downlaps are observed (central and distal sectors, respectively) above horizon S6. Interval 5 is developed along all the continental margin (Fig. 4E), reaching $0.25 \mathrm{~s}$ in thickness (TWT). Reflections are subparallel, with medium to high amplitude in central and distal sectors, respectively (Fig. 9). In the latter, reflections acquire irregular configurations.
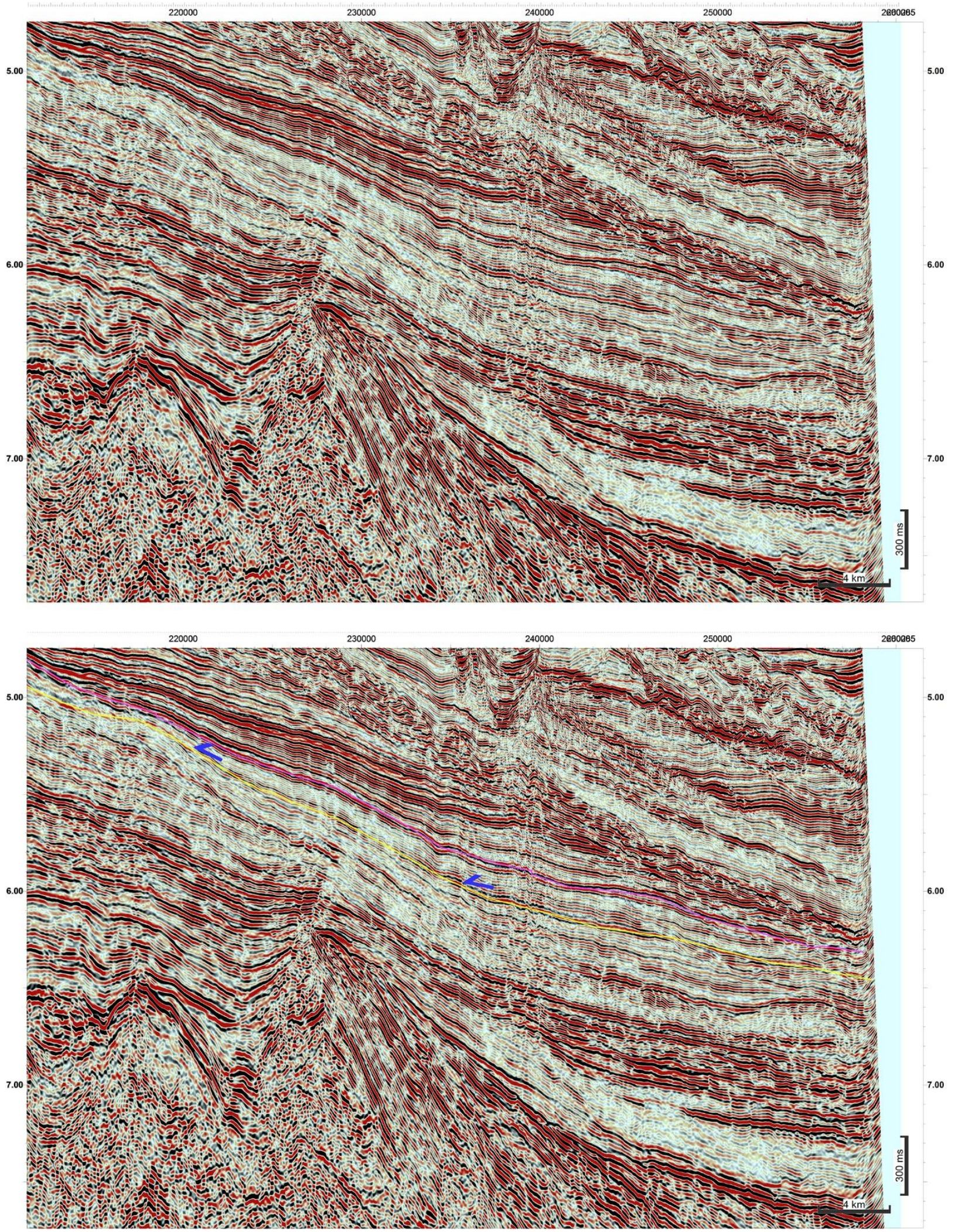

Fig. 9. Representative seismic facies of Interval 5. Reflection terminations are shown. Vertical scale in TWT (s). 
Interval 6 is bounded by horizons S6 (below) and S7 (above). Truncations are observed below S7, whereas above onlaps (central sector) and downlaps (distal sector) exist. Interval 6 is developed along all the continental margin, starting from the lower slope (Fig. 4F). It reaches a maximum thickness of $0.30 \mathrm{~s}$ (TWT). Parallel to subparallel reflections, with high amplitude and continuity are the typical seismic facies of this interval (Fig. 10).
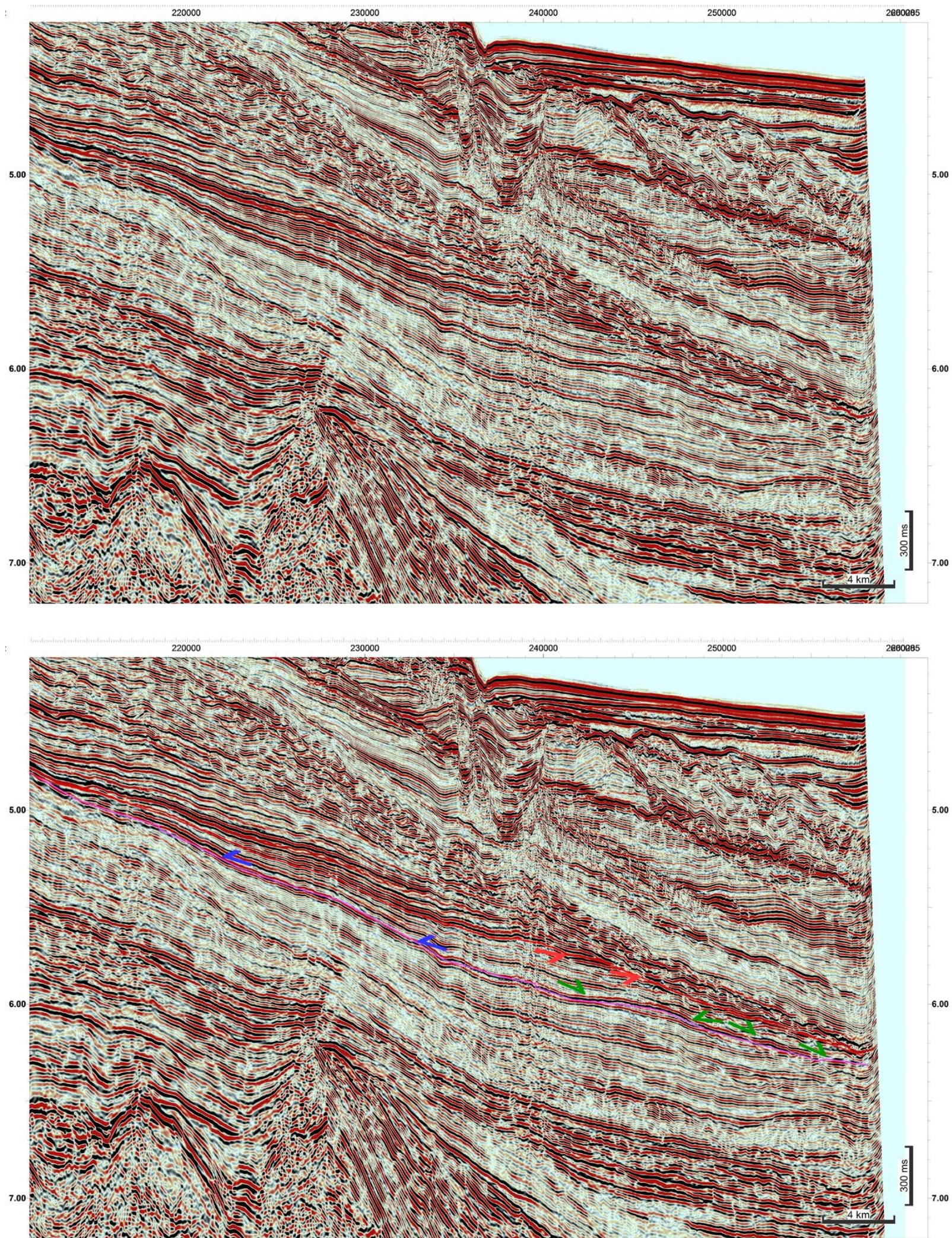

Fig. 10. Uninterpreted and interpreted 2D dip seismic line showing representative seismic facies of Interval 6. Reflection terminations are shown. Vertical scale in TWT (s). 
Tab. 1. Seismic horizons identified in the Paleocene sequence. Legend: CCS = correlative conformity surface; $D l=$ downlap; $O l=$ onlap; $\mathrm{Tr}=$ truncation and; $\mathrm{U}=$ unconformity.

\begin{tabular}{|c|c|c|c|}
\hline Horizon & Meaning & Criteria & Age \\
\hline S7 & $\mathrm{U}+\mathrm{CCS}$ & $\begin{array}{c}\text { Above: Double } \mathrm{Dl}, \mathrm{Ol} \\
\text { Below: Tr. }\end{array}$ & Paleocene-Eocene \\
\hline S6 & & Above: $D l, O l$ & \\
\hline S5 & & Above: $D l, O l$ & \\
\hline S4 & $\mathrm{U}+\mathrm{CCS}$ & $\begin{array}{c}\text { Above: } O l \\
\text { Below: } \mathrm{Tr}\end{array}$ & \\
\hline $\mathrm{S} 3$ & & Above: $D l$ & \\
\hline S2 & & Above: $D l, O l$ & \\
\hline S1 & $\mathrm{U}+\mathrm{CCS}$ & $\begin{array}{c}\text { Above: Double } D l \\
\text { Below: Tr }\end{array}$ & Maastrichtian-Danian \\
\hline
\end{tabular}

\section{Discussion}

In the base of the sequence (Intervals 1 and 2) fans and sedimentary waves were inferred to be present. The existence of them evidences a rather important sedimentary supply in a regressive context (Figs. 5 and 6).

The sedimentary waves deserve some additional comments. They comprise wavy and mounded facies within the Interval 1 (Fig. 5). These so far undescribed conspicuous sedimentary features, consistent with the action of bottom currents (i.e., contourites), are located between 4,500 and 6,000 meters of sea depth and are restricted to the southwestern portion of the continental margin.

Wavelenghts vary approximately between 8 and $14 \mathrm{~km}$, and thickness is of at least 250 meters. Amplitudes of the sedimentary waves are rather low. However, amplitude anomalies do exist in the valleys between the crests. These sediments, which show onlap infill, are the result of the preferential transport and deposition following the paleotopography. Amplitude anomalies between muddy contourite drifts have been already described in a Cretaceous mixed contouritic-turbiditic system (Creaser et al., 2017). In the case of the Paleocene, the continuity and seismic character however do not allow to reject the pelitic nature.

Unfortunately, the scarcity of seismic data in the region of the sedimentary waves does not allow constructing adequate isopach or structural contour maps. Hence, the exact distribution, thickness variation and orientation of these features cannot be assessed.

In Interval 3, downlaps recognized over horizon S3 (Fig. 7) indicate a basinward migration of the shoreline, due to an increase of sedimentary supply in relation to the available accommodations space. The low amplitudes suggest a predominance of one type of lithology.

However, the top of the Paleocene sequence (Intervals 4, 5 and 6) shows a marked transgressive character. Indeed, a landward migration of the shoreline is interpreted, in a context of rising base level and an accommodation space greater than sedimentary supply. This gives as a result a retrograding stacking pattern (Figs. 8, 9, 10).
In the Interval 4 there is a low impedance contrast (Fig. $8)$, which would indicate a low variation in the properties of the sediments. However, Intervals 5 and 6 show greater contrast (Figs. 9 and 10), suggesting certain alternance of lithologies.

From the point of view of the petroleum systems, the Paleocene sequence can be considered from the points of view of source rocks, seal rocks and reservoir rocks. As a potential source rock, is unlikely that the organic rich facies reached the oil window, except perhaps in distal positions of the basin (Morales et al., 2017b).

As a seal rock, the Paleocene sequence (particularly Intervals 4 to 6) constitutes an excellent regional seal. This has been demonstrated in the offshore of Uruguay through the disappearance of hydrocarbon fluid inclusions in Cenozoic deposits in both Lobo and Gaviotín wells (which do exist in stratigraphically older sequences; Soto et al., 2015) and the non-discovery of hydrocarbons in a large Oligocene turbiditic fan drilled by Total in 2016.

As a reservoir rock, the recognition of turbiditic fans and sedimentary bodies deposited (or reworked) by contour currents not far from potential Cretaceous source rocks open interesting possibilities for hydrocarbon potential exploration. However, new studies such as impedance analyses (or ideally direct sampling of the intervals of interest) should be performed in order to corroborate the sandy character of the deposits and its potential hydrocarbon charge.

\section{Conclusion}

Offshore Uruguay, the Paleocene sequence reaches a maximum thickness of $1 \mathrm{~s}$ (TWT), thus exceeding 1,000 m (Fig. 11). Through the analysis of $2 \mathrm{D}$ reflections seismic sections, seven seismic horizons were identified in the Paleocene sequence. These horizons bound six sedimentary intervals with different characteristics. Hence, complexity of this sequence is greater than early recognized.

Globally, the Paleocene sequence would represent a regressive-transgressive cycle. If, as stated herein, horizon S4 
constitutes an unconformity, the Paleocene would be constituted in fact by two depositional sequences.

Paleocene sediments were deposited along the entire Uruguayan continental margin, exceeding 1,000 $\mathrm{m}$ of total thickness, particularly in the southwestern portion of the margin. This is in sharp contrast with the 160 metros drilled by the Gaviotín well, where only the Lower Paleocene is represented.

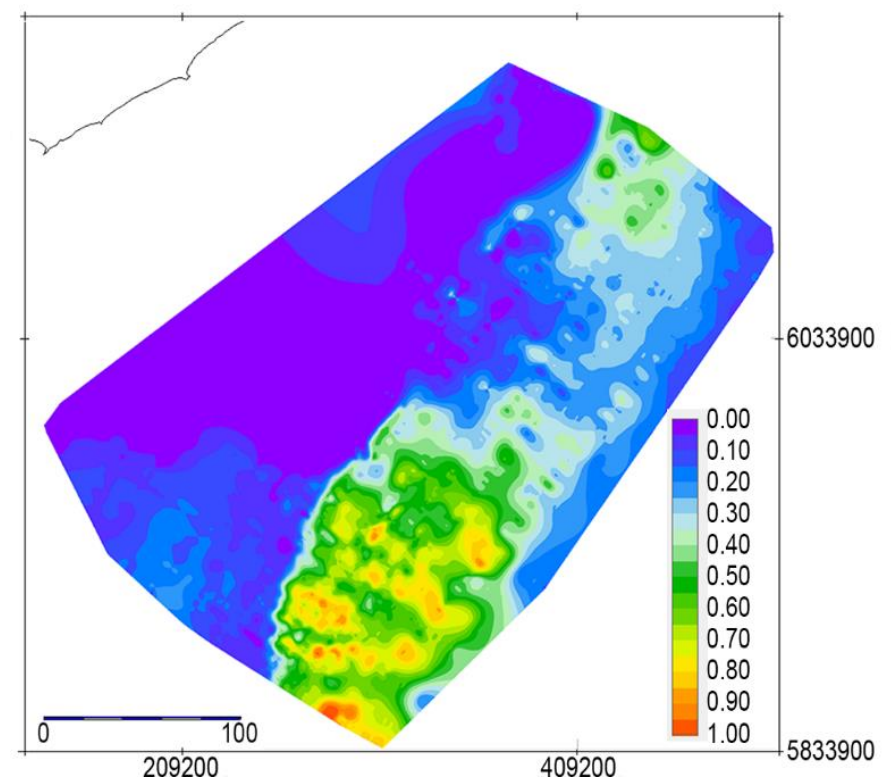

Fig. 11. Isopach map (TWT in s) of the entire Paleocene sequence. Scale in kilometers.

The identification of turbiditic and contouritic sandstones close to the expected Cretaceous source rocks, in addition to the importance of the overlying Paleocene shales as a regional seal, opens interesting exploratory perspectives in the continental margin of Uruguay.

\section{Acknowledgment}

We are indebted to ANCAP, which allowed the use of seismic sections, and to IHS, which granted licenses of the Kingdom Suite software to the Instituto de Ciencias Geológicas. This is a contribution to the CSIC Project "Depósitos sedimentarios en ambientes marinos profundos del margen continental de Uruguay: implicancias en la exploración de hidrocarburos" (responsible: Dra. Ethel Morales).

\section{References}

Catuneanu, O., 2006. Principles of sequence stratigraphy. ix +375 pp. Elsevier. https://doi.org/10.1016/j.coal.2006.08.007

Catuneanu, O., Abreu, V., Bhattacharya, J.P., Blum, M.D., Dalrymple, R.W., Eriksson, P.G., Giles, K.A., 2009. Towards the standardization of sequence stratigraphy. Earth Science Reviews 92 (1-2), 1-33. https://doi.org/10.1016/j.earscirev .2008 .10 .003
RESEARCH PAPER

Conti, B., Perinotto, J.A.J., Veroslavsky, G., Castillo, M.G., de Santa Ana, H., Soto. M., Morales, E., 2017. Speculative petroleum systems of the southern Pelotas Basin, offshore Uruguay. Marine and Petroleum Geology 83, 1-25. https://doi.org/10.1016/j.marpetgeo.2017.02.022

Creaser, A., Hernández-Molina, F.J., Badalini, G., Thompson, P., Walker, R., Soto, M., Conti, B., 2017. A Late Cretaceous mixed (turbidite-contourite) system along the Uruguayan Margin: Sedimentary and palaeoceanographic implications. Marine Geology 390, 234-253. https://doi.org/10.1016/j.margeo. 2017.07.004

Daners, G., Guerstein, G.R., 2004. Dinoflagelados del Maastrichtiense- Paleogeno en la Formación Gaviotín, cuenca Punta del Este. In: Veroslavsky, G., Ubilla, M., Martínez., S. (eds.), Cuencas sedimentarias de Uruguay; Geología, Paleontología y Recursos Naturales, Cenozoico, DIRAC, Montevideo, p. 37-62

Goso, C., Perea, D., 2004. El Cretácico post-basáltico de la Cuenca litoral del río Uruguay: geología y paleontología. In: Veroslavsky, G., Ubilla, M., Martínez, S. (eds.), Cuencas sedimentarias de Uruguay: geología, paleontología y recursos naturales. Mesozoico. 2da. ed. DIRAC, Montevideo, 143-171.

Hernández-Molina, F.J., Campbell, S., Badalini, G., Thompson, P., Walker, Soto, M., Conti, B., Preu, B., Thieblemont, A., Hyslop, L., Miramontes, E., Morales, E., 2017. Large bedforms on contourite terraces: Sedimentary and conceptual implications. Geology. 46: 27-30. https://doi.org/10.1130/G39655.1

Martínez, S., Veroslavsky, G., 2004. Registros continentales no depositacionales del Terciario Temprano. In: Veroslavsky, G., Ubilla, M., Martínez, S. (eds.), Cuencas sedimentarias de Uruguay: geología, paleontología y recursos naturales. Cenozoico. DIRAC, Montevideo, 63-82.

Morales, E., Chang, H.K., Soto, M., Santos Correa, F., Veroslavsky, G., de Santa Ana, H., Conti, B., Daners, G., 2017a. Tectonic and stratigraphic evolution of the Punta del Este and Pelotas basins (offshore Uruguay). Petroleum Geoscience 23(4), 415-427. https://doi.org/10.1144/ petgeo2016-059

Morales, E., Chang, H.K., Soto, M., Veroslavsky, G., Conti, B., de Santa Ana, H., Santos Correa, F., 2017b. Speculative petroleum systems of the Punta del Este Basin (offshore Uruguay). Brazilian Journal of Geology 47, 645-656. https://doi.org/10.1590/2317-4889201720170078

Raggio, F., Gerster, R., Welsink, H., 2011. Cuencas del Salado y Punta del Este. In: Kozlowski, E., Legarreta, L., Boll, A. y Marshall, P. (eds.), Simposio Cuencas Argentinas. VIII Congreso de Exploración y Desarrollo de Hidrocarburos, Mar del Plata, pp. 81-96.

Soto, M., Conti, B., Gristo, P., de Santa Ana, H., 2015. Direct oil and gas evidences from Punta del Este Basin, offshore Uruguay: new data from fluid inclusions. AAPG International Conference and Exhibition, 13-16 September 2015, Melbourne. https://doi.org/10.1190/ice2015-2207049

Ucha, N., de Santa Ana, H., Veroslavsky, G., 2004. La Cuenca Punta del Este: geología y potencial hidrocarburífero. In: Veroslavsky, G., Ubilla, M., Martínez, S. (eds.), Cuencas Sedimentarias de Uruguay: Geología, Paleontología y recursos naturales - Mesozoico. DIRAC, Montevideo, pp. 173-192. 